\title{
PRODUCTION OF Candida BIOMASSES FOR HEAVY METAL REMOVAL FROM WASTEWATERS
}

\author{
Gülşah MERSİN ${ }^{1 *}$, Ünsal AÇIKEL ${ }^{2}$ \\ ${ }^{1}$ Uşak University, Technology Transfer Office, Project Support Unit, Rectorate Ground Floor Office No: 106, 64000, Uşak, \\ TURKEY \\ ${ }^{2}$ Cumhuriyet University, Faculty of Engineering, Chemical Engineering Department, 58140, Sivas, TURKEY
}

Cite this article as:

Mersin G., Açıkel Ü. 2021. Production of Candida biomasses for heavy metal removal from wastewaters. Trakya Univ J Nat Sci, 22(1): 67-76, DOI: $10.23902 /$ trkjnat.817451

Received: 28 October 2020, Accepted: 06 April 2021, Online First: 11 April 2021, Published: 15 April 2021

\section{Edited by: \\ Bülent Yorulmaz \\ *Corresponding Author: \\ Gülşah Mersin \\ gulsah.mersin@gmail.com}

ORCID iDs of the authors:

GM. orcid.org/0000-0002-2852-6114

ÜA. orcid.org/0000-0003-4969-8502

Key words:

Bioaccumulation

Heavy metal cations

Wastewater

Candida

Biomass

\begin{abstract}
Yeasts can accumulate heavy metals and grow in acidic media. In the present study, it was shown that Candida yeasts in an aqueous solution accumulate single $\mathrm{Cu}(\mathrm{II})$ and $\mathrm{Ni}$ (II) cations. The effect of heavy metal ions on the specific growth rate of biomasses and the uptake of metal ions during the growth phase was investigated in a batch system. Bioaccumulation efficiency decreased with increasing metal ion concentrations at constant sucrose concentrations. Both the specific growth rate and the biomass concentration were more inhibited in the bioaccumulation media containing $\mathrm{Ni}$ (II) ions singly as compared with the bioaccumulation media containing $\mathrm{Cu}(\mathrm{II})$ ions singly. The maximum specific growth rate and the saturation constant of yeasts were examined with a double-reciprocal form of Monod equation. Metal uptake performance decreased from $81.68 \%$ to $46.28 \%$ with increasing Ni(II) concentration from $25 \mathrm{mg} / \mathrm{L}$ to $250 \mathrm{mg} / \mathrm{L}$ for Candida lipolytica. Candida biomasses may be an alternative way of removal of heavy metals from wastewaters and may constitute a sample to produce new biomass. The study showed that Candida yeasts can be used as economical biomass due to their metal resistance and efficient production.
\end{abstract}

\begin{abstract}
Özet: Mayalar, asidik ortamda büyüyebilir ve ağır metalleri biriktirebilir. Bu çalışma, Candida türü mayaların sulu çözeltilerden tekli $\mathrm{Cu}(\mathrm{II})$ ve Ni(II) katyonlarını biriktirdiğini göstermiştir. Ağır metal iyonlarının, biyokütlelerin spesifik büyüme hızı ve büyüme periyodu boyunca metal iyonlarını giderimi üzerindeki etkisi, bir kesikli sistemde araştırılmıştır. Sabit sakaroz derişiminde, metal iyonu derişimi arttıkça, biyobirikim verimi azalmıştır. Hem spesifik büyüme hızı hem de biyokütle konsantrasyonu, tek başına $\mathrm{Cu}$ (II) iyonları içeren biyoakümülasyon ortamına kıyasla Ni(II) iyonları içeren biyoakümülasyon ortamında daha fazla inhibe edilmiştir. Mayaların maksimum özgül büyüme hızı ve doygunluk sabiti, Monod denkleminin çift-karşılıklı formu ile incelenmiştir. Candida lipolytica'nın metal giderim performansı Ni(II) derişiminin $25 \mathrm{mg} / \mathrm{L}$ 'den $250 \mathrm{mg} / \mathrm{L}$ 'ye çıkmasıyla \% 81,68'den \% 46,28'e düşmüştür. Candida biyokütleleri, ağır metallerin atık sulardan gideriminde alternatif bir yol olabilir ve yeni biyokütle üretimi için bir örnek oluşturabilir. Bu çalışma, Candida mayalarının, metal direnci ve verimli üretimleri nedeniyle ekonomik biyokütle olarak kullanılabileceğini göstermektedir.
\end{abstract}

\section{Introduction}

Clean water plays a vital role in living organisms. Industrial activities cause water contamination due to chemical, physical and biological components in water bodies. One of the important sources of water contamination is heavy metals. The presence of heavy metals in the environment may cause significant hazards to both animals and humans. Even in trace amounts, heavy metals play a vital role in human metabolic systems, and high concentrations of trace elements are toxic, and they cause physiological and neurological hazards (Tchounwou et al. 2012). Several methods are used for the treatment of wastewater effluents. These methods include chemical precipitation, ion exchange, adsorption, membrane filtration, reverse osmosis, solvent extraction etc. (Wolowiec et al. 2019). Some adsorbents such as clay, zeolite, fly ash, agro wastes, and chitin have been reported as low-cost for the removal of contaminations from aqueous solutions. Biomass can be derived from both vegetables and animals, either living or dead, and is used as an adsorbent to efficiently remove heavy metals from wastewaters. Biomasses have some advantages such as high efficiency, minimal sludge formation, regeneration, and no additional supplementary of nutrients (Tripathi \& Ranjan 2015). Yeasts which are used 
in the enzymatic industry and medicine can survive in a medium containing low or high concentrations of heavy metals (Cottet et al. 2020). One of the most important microbial source for biosorption of heavy metals is Candida species (Luna et al. 2016), which were shown to play an important role in the accumulation of metal ions (Honfi et al. 2016, Luk et al. 2017). Metal uptake capacity of Candida species under various experimental conditions depends on the metal type and the yeast species itself (Legorreta-Castañeda et al. 2020). Bioaccumulation, which contains some processes as complex formation, ion transfer, adsorption, and chelation is applied to eliminate toxic effects of heavy metals as a cheap, efficient, and green technology (Redha 2020, Fadel et al. 2017). The biosorption of metals is affected by several factors such as $\mathrm{pH}$, temperature, concentration, type of biomass, contact time, and type of metal ions in solution. Bioaccumulation based on the accumulation of metals in living microorganisms is metabolism dependent (Açıkel \& Alp 2009). The bioaccumulation of heavy metals by living cells contains two stages. The first step is very fast due to surface adsorption carried out on the surface of the microorganism with physical adsorption and ion exchange. The second step is the intracellular metal uptake stage which occurs slower due to the metabolic activity of microorganisms (Podder \& Majumder 2019). Bioaccumulation has been investigated in many studies for the removal of heavy metals from wastewaters. $\mathrm{Cd}$ (II) removal by Candida tropicalis, $\mathrm{Cu}(\mathrm{II})$ removal by $C$. utilis, $\mathrm{Pb}$ (II) removal by $C$. albicans can be given as examples (Gönen \& Aksu 2008, Baysal et al. 2009, Rehman \& Anjum 2011). In the bioaccumulation process, high concentrations of heavy metals may interact with microorganisms which would result in prolonged lag time and reduced growth rate. Therefore, microbial growth kinetics are affected by heavy metals. Nickel is a trace element necessary for microbial growth, but it may cause oxidative stress and disruption of the cell membrane when in higher concentrations, (Fashola et al. 2016). $\mathrm{Cu}(\mathrm{II})$ is one of the most stable metals and shows a high affinity for metalloproteins in cells (Waldron $\&$ Robinson 2009). Some microorganisms use $\mathrm{Cu}$ as a catalyzer for electron transfer reactions in cell metabolism. Microorganisms have different metal-binding proteins due to their nature (Dupont et al. 2011). Mathematical description of the growth kinetics can be explained by the Monod equation (Şengör et al. 2009), which is widely used to describe the empirical microbial growth of microorganisms as a simple model (1).

$$
\mu=\frac{\mu_{\max } S}{K_{s}+S}
$$

Where $\mu_{\max }$ is the maximum growth rate when there is enough substrate supplied to the cell and the value exceeds the limiting substrate concentration, $S>K_{s}$. The constant $K_{s}$ is the saturation constant or half of the velocity constant and is equal to the concentration of the ratelimiting substrate when the specific growth rate is equal to one-half of the maximum specific growth rate (Monod 1949, Liu 2007). Microorganism cell consists of an outer cover called a cell wall and contains a variety of functional sites such as amines, phosphates, sulfates, phenols, and hydroxyls with the ability for adsorption of metal ions (Javanbakht et al. 2013, Cottet et al. 2020). Metal ion adsorption by microorganisms is calculated by the mass balance equation (2).

$$
q_{e}=\frac{\left(C_{o}-C_{e}\right) V}{m}
$$

Where $q_{e}$ is metal ion uptake per unit mass of biomass at equilibrium (mg/g biomass), $C_{e}$ is the metal ion concentration in solution at equilibrium $(\mathrm{mg} / \mathrm{L}), C_{o}$ is the initial metal ion concentration in solution $(\mathrm{mg} / \mathrm{L}), V$ is volume of the initial metal ion's solution (L), and $m$ is the mass of biomass (g) (Zha et al. 2020).

In this study, bioaccumulation, and growth properties of Candida biomasses for the uptake of $\mathrm{Cu}$ (II) and $\mathrm{Ni}$ (II) ions were investigated as a function of molasses sucrose and metal ion concentrations. Molasses sucrose was used as the main carbon source. The inhibition effects of metal ions on specific growth rates were examined. The results showed that Candida species can be used as a biosource for efficient removal of heavy metals from aqueous solutions at low costs.

\section{Materials and Methods}

Candida membranafiens (C. membranafiens-ATCC $\left({ }^{\circ}\right.$ 201377тM), C. utilis (C. utilis-ATCC® 9950), $C$. tropicalis (C. tropicalis-ATCC $\AA \quad 13803^{\mathrm{TM}}$ ) and $C$. lipolytica (C. lipolytica-ATCC $\left(9733^{\mathrm{TM}}\right.$ ) were obtained from the Biology Department of Ankara University. $\left(\mathrm{NH}_{4}\right)_{2} \mathrm{SO}_{4}$ and $\mathrm{K}_{2} \mathrm{PO}_{4}$ were purchased from SigmaAldrich Company. Molasses sucrose was supplied from a sugar factory in Ankara (Turkey). Molasses consisting of $47-48 \%$ sugar was used as the sole carbon source for the growth of the microorganisms. Total sugars constitute of the system included approximately $50 \%$ (w/w) of molasses, ash $11 \%(\mathrm{w} / \mathrm{w})$, and total nitrogen compounds $7-8 \%(w / w)$. Non-sugar part of molasses contained minerals and trace elements such as $\mathrm{K}^{+}, \mathrm{Na}^{+}, \mathrm{Ca}^{2+}, \mathrm{Mg}^{2+}$, $\mathrm{Fe}^{2+}, \mathrm{Cl}^{-}, \mathrm{SO}_{4}^{-}, \mathrm{PO}_{4}^{-}, \mathrm{NO}_{3}{ }^{-}$and metal oxides (as ferric 0.4-2.7\%) (Açıkel \& Alp 2009).

\section{Microorganism growth and bioaccumulation media}

Yeasts were grown in aqueous media containing (1-10 $\mathrm{g} / \mathrm{L})$ molasses sucrose, $(1 \mathrm{~g} / \mathrm{L})\left(\mathrm{NH}_{4}\right)_{2} \mathrm{SO}_{4}$ and $(1 \mathrm{~g} / \mathrm{L})$ $\mathrm{K}_{2} \mathrm{PO}_{4}$ at $25{ }^{\circ} \mathrm{C}(\mathrm{pH}: 4.0)$. The growth and cultivation media were sterilized in an autoclave operating at $121^{\circ} \mathrm{C}$ at 0.99 bar for 15 minutes. Subcultures were grown for 4 days at a rotating speed of $150 \mathrm{rpm} .1 \mathrm{~g} / \mathrm{L} \mathrm{Cu}$ (II) and $\mathrm{Ni}$ (II) stock solutions were prepared by diluting $\mathrm{Cu}$ $\left(\mathrm{NO}_{3}\right)_{2} \cdot 3 \mathrm{H}_{2} \mathrm{O}$ and $\mathrm{Ni}\left(\mathrm{NO}_{3}\right)_{2} \cdot 6 \mathrm{H}_{2} \mathrm{O}$ in distilled water. The $\mathrm{pH}$ of the working solutions was adjusted to desired value by adding $0.1 \mathrm{~N} \mathrm{NaOH}$ and $\mathrm{HNO}_{3}(\mathrm{pH}: 4.0)$. The yeasts were adapted to the metal ions in culture medium by exposing them to single $\mathrm{Cu}$ (II) and $\mathrm{Ni}$ (II) ions during the growth phase to increase their metal resistance. The resistance to $\mathrm{Cu}(\mathrm{II})$ and $\mathrm{Ni}(\mathrm{II})$ ions was investigated as functions of initial metal ion and molasses sucrose 
concentrations and the yeasts were adapted to higher metal ion concentrations after the first inoculation. Each yeast was adapted to each metal ion in its culture medium. Adapted yeasts were obtained from subcultures with different concentrations of metal ions in the range of 25$250 \mathrm{mg} / \mathrm{L}$ in varying concentrations from $1 \mathrm{~g} / \mathrm{L}$ to $20 \mathrm{~g} / \mathrm{L}$ for molasses. Yeast cultures which were resistant to 25 $\mathrm{mg} / \mathrm{L} \mathrm{Cu}(\mathrm{II})$ and $\mathrm{Ni}(\mathrm{II})$ ions at $10 \mathrm{~g} / \mathrm{L}$ molasses sucrose concentration was used for further inoculation. $1 \mathrm{~mL}$ culture medium was used to inoculate the next culture medium containing $50 \mathrm{mg} / \mathrm{L} \mathrm{Cu}$ (II) and $\mathrm{Ni}(\mathrm{II})$ ions at the same molasses sucrose concentration when growth culture reached to the exponential growth phase. Adaptation experiments by Candida species were carried out in $250 \mathrm{~mL}$ flask with $100 \mathrm{~mL}$ working volume.

\section{Analytical procedure}

$5 \mathrm{~mL}$ samples were centrifuged at 3000xg for $5 \mathrm{~min}$ and the supernatant fluid was analyzed for metal ions. The precipitated cells were used for determination of the dry weight of the biomass and the biomass concentration. Yeast pellets were dried until constant mass at $60^{\circ} \mathrm{C}$ for $24 \mathrm{~h}$. The amount of total metal ions was calculated from the calibration graph. Microorganism concentration was measured at $360 \mathrm{~nm}$ using a calibration curve relating the wet weight of the biomass to the dry weight of the biomass at $25^{\circ} \mathrm{C}$. Residual metal concentrations were measured at $460 \mathrm{~nm}$ and $340 \mathrm{~nm}$ for $\mathrm{Cu}(\mathrm{II})$ and $\mathrm{Ni}(\mathrm{II})$, respectively by using Sodium diethyldithiocarbamate as the complexing agent (Sandell, 1950).

\section{Abbrevations}

$\mu \quad$ : Specific growth rate of yeast $\left(\mathrm{h}^{-1}\right)$

$\mu_{\max }:$ Maximum specific growth rate $\left(\mathrm{h}^{-1}\right)$

$\mathrm{C}_{\mathrm{iCu}} \quad$ : Initial $\mathrm{Cu}$ (II) ion concentration $(\mathrm{mg} / \mathrm{L})$

$\mathrm{C}_{\mathrm{iNi}} \quad$ : Initial Ni(II) ion concentration $(\mathrm{mg} / \mathrm{L})$

$\mathrm{Cac}_{\mathrm{Cu}}$ : Bioaccumulated $\mathrm{Cu}(\mathrm{II})$ ion concentration at any time $(\mathrm{mg} / \mathrm{L})$

$\mathrm{C}_{\mathrm{ac}, \mathrm{Ni}}$ : Bioaccumulated $\mathrm{Cu}(\mathrm{II})$ ion concentration at any time $(\mathrm{mg} / \mathrm{L})$

$\mathrm{K}_{\mathrm{s}} \quad$ : Saturation constant $(\mathrm{g} / \mathrm{L})$

qCu : Specific $\mathrm{Cu}$ (II) uptake defined as bioaccumulated $\mathrm{Cu}$ (II) ion quantity per gram of dried yeast at the end of microbial growth $(\mathrm{mg} / \mathrm{g})$

$\mathrm{q}_{\mathrm{Ni}} \quad$ : Specific Ni(II) uptake defined as bioaccumulated Ni(II) ion quantity per gram of dried yeast at the end of microbial growth $(\mathrm{mg} / \mathrm{g})$

$\mathrm{S}_{\mathrm{o}} \quad$ : Initial sucrose concentration $(\mathrm{g} / \mathrm{L})$

$\mathrm{S} \quad$ : Sucrose concentration $(\mathrm{g} / \mathrm{L})$

$\mathrm{T}$ : Temperature $\left({ }^{\circ} \mathrm{C}\right)$

$\mathrm{t} \quad$ : Reaction time $(\mathrm{h})$

$\mathrm{X}$ : Dried yeast concentration in feed medium at any time $(\mathrm{g} / \mathrm{L})$

$\mathrm{X}_{\max }$ : Maximum dried yeast concentration $(\mathrm{g} / \mathrm{L})$

\section{Results and Discussions}

Microorganism growth and bioaccumulation properties were investigated as functions of initial metal ion and molasses sucrose concentrations at $\mathrm{pH}$ : 4.0 and $25^{\circ} \mathrm{C}$. The uptake yield (uptake \%) was described as the ratio of bioaccumulated concentration of metal ion at the end of growth to the initial metal ion concentration. The results were expressed as the units of bioaccumulated metal ion concentration $\left(\mathrm{C}_{\mathrm{ac}, \mathrm{m}}: \mathrm{mg} / \mathrm{L}\right)$ and specific metal ion uptake determined as the amount of metal ion per unit of dry weight of cells $\left(\mathrm{q}_{\mathrm{m}}: \mathrm{mg} / \mathrm{g}\right)$, dried cell concentrations at any time $(X: g / L)$, specific growth rate of yeast $\left(\mu: h^{-1}\right)$. The specific growth rate of Candida yeasts was determined from the slope of $\ln \mathrm{X}$ versus time plot at the exponential growth phase. The results indicated that biomass concentration was related to the metal concentrations in fermentation medium and the physiological properties of the yeasts. The ability of metal uptake by metal adapted yeasts were different due to the physiological properties of the yeasts. All experiments were conducted at $25^{\circ} \mathrm{C}$. The effect of temperature on metal bioaccumulation depends on cellular metabolism. Uptake capacity of heavy metals by microorganisms decreased at low temperatures whereas high temperatures could damage cells and reduced uptake levels (Brady \& Duncan 1994).

\section{Effect of initial $p H$ on microbial growth}

Effect of initial $\mathrm{pH}$ on specific growth rate and maximum microorganism concentrations of Candida yeasts was examined in the $\mathrm{pH}$ range of 2.0-5.0 at $10 \mathrm{~g} / \mathrm{L}$ molasses sucrose concentration. Maximum specific growth rate and microorganism concentrations were obtained at $\mathrm{pH}$ : 4.0. Initial $\mathrm{pH}$ was a major factor in the quantity of metal ion bioaccumulation. All Candida species showed growth at $\mathrm{pH}$ : 2.0-5.0. The highest value of specific growth rate and microorganism concentration was found as $0.308 \mathrm{~h}^{-1}$ and $3.111 \mathrm{~g} / \mathrm{L}$ respectively using C. lipolytica in metal free media (Table 1). Bioaccumulation experiment was conducted at $\mathrm{pH}: 4.0$ which showed maximum growth.

Effect of initial sucrose concentration on microbial growth

The effect of initial sucrose concentration on growth rates of Candida yeasts in metal-free media was investigated in the sucrose concentration range of 1.0$20.0 \mathrm{~g} / \mathrm{L}$, at $\mathrm{pH}: 4.0$ and $25^{\circ} \mathrm{C}$. The relationship of specific growth rate to substrate concentration was explained with saturation kinetics. It was observed that the specific growth rate and biomass concentration increased with increasing initial sucrose concentration up to $20.0 \mathrm{~g} / \mathrm{L}$. Microorganism concentration increased from $1.52 \mathrm{~g} / \mathrm{L}$ to $3.48 \mathrm{~g} / \mathrm{L}$ with an increase in the initial sucrose concentration from 1.0 to $20.0 \mathrm{~g} / \mathrm{L}$ for $C$. lipolytica in metal-free media (Fig. 1). Lower growth performance among the yeast cells was seen using $C$. utilis. We have found that molasses was a suitable carbon source for fermentation medium of Candida species. It was also reported in previous studies that molasses could be used as feasible and economical for microbial growth (Aksu \& Dönmez 2000, Açıkel \& Alp 2009, Evirgen \& Sağ Açıkel 2014). 
Effect of initial metal ion concentrations on growth of

\section{Candida species}

The effect of initial $\mathrm{Cu}(\mathrm{II})$ and $\mathrm{Ni}(\mathrm{II})$ ion concentrations on microbial growth of Candida species were examined at different $\mathrm{Cu}$ (II) and $\mathrm{Ni}(\mathrm{II})$ ion concentrations. The metal ion concentrations in the fermentation the medium varied in the range of 25-250 $\mathrm{mg} / \mathrm{L}$ for $\mathrm{Cu}(\mathrm{II})$ and $\mathrm{Ni}(\mathrm{II})$. The range of molasses sucrose concentrations of prepared fermentation media varied between 1 and $20 \mathrm{~g} / \mathrm{L}$. Both metal ions inhibited specific growth rates and biomass concentrations for all yeasts. We found that the inhibition effect of $\mathrm{Ni}$ (II) ions on specific growth rate and microorganism concentration was higher than $\mathrm{Cu}(\mathrm{II})$ ions for all yeasts. Candida lipolytica showed the highest specific growth rate and microorganism concentration among the yeasts in metal media. Maximum specific growth rate significantly decreased from $0.302 \mathrm{~h}^{-1}$ to $0.278 \mathrm{~h}^{-1}$ with an increase in the initial $\mathrm{Ni}$ (II) concentration from 100 to $200 \mathrm{mg} / \mathrm{L}$ for C. utilis. Inhibition kinetics was determined using the double reciprocal plot of the Monod equation. When initial $\mathrm{Cu}(\mathrm{II})$ and $\mathrm{Ni}(\mathrm{II})$ ion concentrations were increased in the range of $25-250 \mathrm{mg} / \mathrm{L}$, the maximum specific growth rate $\left(\mathrm{h}^{-1}\right)$ of the yeasts decreased whereas saturation constants $\left(K_{s}\right)$ increased (Table 2$)$.

Table 1. Effect of initial $\mathrm{pH}$ on the maximum specific growth rate, maximum dried microorganism concentration in metal-free medium (So: $10 \mathrm{~g} / \mathrm{L} ; \mathrm{T}: 25^{\circ} \mathrm{C}$ ).

\begin{tabular}{ccccccccc}
\hline \hline \multirow{2}{*}{ pH } & \multicolumn{2}{c}{ C. membranaefaciens } & \multicolumn{2}{c}{ C. utilis } & \multicolumn{2}{c}{ C. tropicolis } & \multicolumn{2}{c}{ C. lipolytica } \\
& $\mu_{\max }\left(\mathrm{h}^{-1}\right)$ & $\mathrm{X}_{\max }(\mathrm{g} / \mathrm{L})$ & $\mu_{\max }\left(\mathrm{h}^{-1}\right)$ & $\mathrm{X}_{\max }(\mathrm{g} / \mathrm{L})$ & $\mu_{\max }\left(\mathrm{h}^{-1}\right)$ & $\mathrm{X}_{\max }(\mathrm{g} / \mathrm{L})$ & $\mu_{\max }\left(\mathrm{h}^{-1}\right)$ & $\mathrm{X}_{\max }(\mathrm{g} / \mathrm{L})$ \\
\hline \hline $\mathbf{2}$ & 0.198 & 2.001 & 0.177 & 1.985 & 0.206 & 2.112 & 0.211 & 2.223 \\
$\mathbf{3}$ & 0.241 & 2.552 & 0.222 & 2.443 & 0.253 & 2.601 & 0.261 & 2.751 \\
$\mathbf{4}$ & 0.253 & 2.854 & 0.238 & 2.658 & 0.289 & 2.999 & 0.308 & 3.111 \\
$\mathbf{5}$ & 0.251 & 2.851 & 0.235 & 2.651 & 0.279 & 2.995 & 0.306 & 3.005 \\
\hline \hline
\end{tabular}

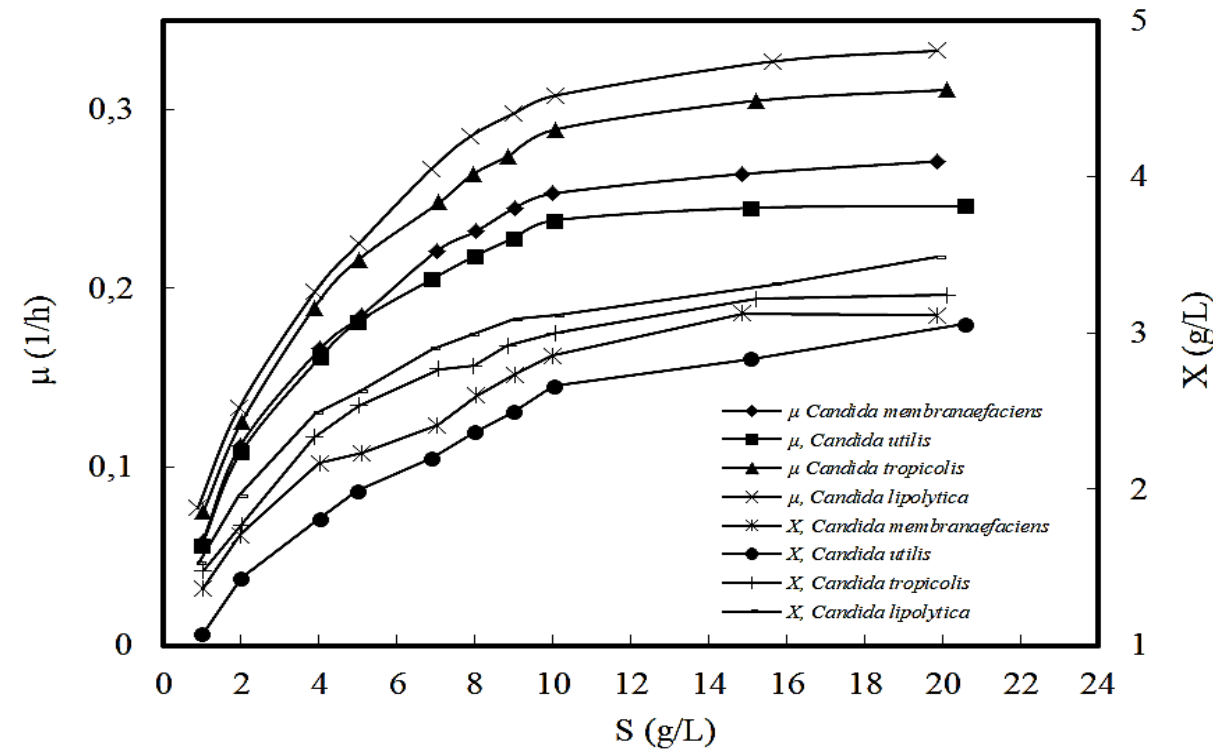

Fig. 1. Effect of initial sucrose concentration on specific growth rate and microorganism concentration for Candida lipolytica, Candida utilis, Candida tropicalis and Candida membranaefaciens (pH: 4.0; SR: $150 \mathrm{rpm}$; T: $25^{\circ} \mathrm{C}$ ).

Table 2. Comparison of the maximum specific growth rates and the saturation constants in the presence of increasing concentrations of single $\mathrm{Cu}(\mathrm{II})$ and $\mathrm{Ni}(\mathrm{II})$ ions (So: $1-20 \mathrm{~g} / \mathrm{L} ; \mathrm{pH}: 4$, T: $25^{\circ} \mathrm{C}$; SR: $150 \mathrm{rpm}$.

\begin{tabular}{cccccccccc}
\hline \hline \multicolumn{2}{c}{ Metal Ion } & \multicolumn{2}{c}{ C. membranefeciens } & \multicolumn{2}{c}{ C. utilis } & \multicolumn{2}{c}{ C. tropicalis } & \multicolumn{2}{c}{ C. lipolytica } \\
$\begin{array}{c}\mathbf{C}_{\mathbf{i C u}} \\
(\mathbf{m g} / \mathbf{L})\end{array}$ & $\begin{array}{c}\mathbf{C}_{\mathbf{i N i}} \\
(\mathbf{m g} / \mathbf{L})\end{array}$ & $\boldsymbol{\mu}_{\max }\left(\mathbf{h}^{-\mathbf{1}}\right)$ & $\mathbf{K}_{\mathbf{s}}(\mathbf{g} / \mathbf{L})$ & $\boldsymbol{\mu}_{\max }\left(\mathbf{h}^{-\mathbf{1}}\right)$ & $\mathbf{K}_{\mathbf{s}}(\mathbf{g} / \mathbf{L})$ & $\boldsymbol{\mu}_{\max }\left(\mathbf{h}^{-\mathbf{1}}\right)$ & $\mathbf{K}_{\mathbf{s}}(\mathbf{g} / \mathbf{L})$ & $\boldsymbol{\mu}_{\max }\left(\mathbf{h}^{-\mathbf{1}}\right)$ & $\mathbf{K}_{\mathbf{s}}(\mathbf{g} / \mathbf{L})$ \\
\hline \hline 25.0 & 0.0 & 0.354 & 5.399 & 0.341 & 5.805 & 0.374 & 4.555 & 0.422 & 5.080 \\
100.0 & 0.0 & 0.337 & 5.354 & 0.341 & 6.472 & 0.363 & 4.677 & 0.388 & 4.568 \\
200.0 & 0.0 & 0.336 & 6.586 & 0.299 & 6.033 & 0.338 & 4.887 & 0.378 & 5.378 \\
250.0 & 0.0 & 0.310 & 6.771 & 0.285 & 6.519 & 0.313 & 4.984 & 0.335 & 4.920 \\
0.0 & 25.0 & 0.346 & 5.725 & 0.319 & 5.600 & 0.352 & 4.243 & 0.345 & 4.473 \\
0.0 & 100.0 & 0.333 & 5.718 & 0.302 & 5.408 & 0.356 & 5.013 & 0.395 & 5.268 \\
0.0 & 200.0 & 0.309 & 7.004 & 0.278 & 6.374 & 0.309 & 5.111 & 0.328 & 4.918 \\
0.0 & 250.0 & 0.267 & 6.265 & 0.264 & 7.196 & 0.284 & 5.269 & 0.317 & 5.796 \\
\hline \hline
\end{tabular}


Candida utilis was sensitive to high concentrations of $\mathrm{Cu}(\mathrm{II})$ with an extension in lag phase duration, correlated with a decrease in yeast production. The increase of $\mathrm{Cu}$ (II) and $\mathrm{Ni}$ (II) concentrations led to a drastic decrease in microbial growth for $C$. utilis. Candida lipolytica was highly resistant to $\mathrm{Cu}$ (II) when compared with three other yeasts. The increase in $\mathrm{Cu}$ (II) concentration also caused a decrease in biomass production. For instance, microorganism concentrations were found as $2.854 \mathrm{~g} / \mathrm{L}$, $2.658 \mathrm{~g} / \mathrm{L}, \quad 2.999 \mathrm{~g} / \mathrm{L}$ and $3.111 \mathrm{~g} / \mathrm{L}$ for $C$. membranaefaciens, $C$. utilis, $C$. tropicalis and $C$. lipolytica, respectively, in the metal-free media (Table 1). Biomass concentrations decreased as $2.666 \mathrm{~g} / \mathrm{L}, 2.456$ $\mathrm{g} / \mathrm{L}, 2.831 \mathrm{~g} / \mathrm{L}$ and $2.968 \mathrm{~g} / \mathrm{L}$ for C. membranaefaciens, C. utilis, C. tropicalis and C. lipolytica, respectively, at $100 \mathrm{mg} / \mathrm{L} \mathrm{Cu}$ (II) concentration (Table 3). The decrease in biomass concentration was found higher for fermentation medium containing $100 \mathrm{mg} / \mathrm{L} \mathrm{Ni(II).} \mathrm{When} \mathrm{initial} \mathrm{Ni(II)}$ concentration was $100.0 \mathrm{mg} / \mathrm{L}$, microorganism concentrations were found as $2.574 \mathrm{~g} / \mathrm{L}, 2.371 \mathrm{~g} / \mathrm{L}, 2.735$ $\mathrm{g} / \mathrm{L}$ and $2.868 \mathrm{~g} / \mathrm{L}$ for $C$. membranaefaciens, C. utilis, $C$. tropicalis and $C$. lipolytica, respectively (Table 3 ).

\section{Bioaccumulation experiments}

The combined effect of heavy metals and molasses sucrose on the bioaccumulation properties of adapted Candida yeasts was investigated. Initial metal ion concentration in the fermentation medium varied in the range $25-250 \mathrm{mg} / \mathrm{L}$ for $\mathrm{Cu}(\mathrm{II})$ and $\mathrm{Ni}$ (II) at changing sucrose concentrations in the range of $1-20 \mathrm{~g} / \mathrm{L}$. We found that bioaccumulated $\mathrm{Cu}(\mathrm{II})$ and $\mathrm{Ni}(\mathrm{II})$ ions and microbial growth increased with increasing initial molasses sucrose concentrations for all Candida yeasts. The uptake performance of $\mathrm{Cu}(\mathrm{II})$ ions was higher than $\mathrm{Ni}(\mathrm{II})$, and $C$. lipolytica showed the maximum removal efficiency in a medium containing both single metal ions. An increase in sucrose concentration significantly increased the growth and metal uptake capacity of the microorganisms. The amount of $\mathrm{Cu}(\mathrm{II})$ and $\mathrm{Ni}(\mathrm{II})$ ions uptake per gram dry microorganism increased with increasing the initial metal concentrations up to $250 \mathrm{mg} / \mathrm{L}$. We found that microbial growth was supported by increasing initial sucrose concentrations in metal- stressed fermentation media. In other words, bioaccumulation of $\mathrm{Cu}$ (II) and $\mathrm{Ni}(\mathrm{II})$ ions by Candida species was metabolism dependent. Specific $\mathrm{Cu}$ (II) uptake was determined as $31.77 \mathrm{mg} / \mathrm{g}, 29.71 \mathrm{mg} / \mathrm{g}$, $33.04 \mathrm{mg} / \mathrm{g}$, and $34.39 \mathrm{mg} / \mathrm{g}$ for C. membranaefaciens, $C$. utilis, C. tropicalis, C. lipolytica, respectively, at fermentation media containing $10 \mathrm{~g} / \mathrm{L}$ constant sucrose and $200 \mathrm{mg} \mathrm{Cu}$ (II) mg/L (Fig. 4). At the same conditions, the specific $\mathrm{Ni}$ (II) uptake significantly decreased for all yeasts in medium containing $\mathrm{Ni}$ (II) ions when compared to $\mathrm{Cu}(\mathrm{II})$ ions. For example, the specific growth rates were obtained in a medium containing $200 \mathrm{mg} \mathrm{Ni}(\mathrm{II}) / \mathrm{L}$ and 10 $\mathrm{g} / \mathrm{L}$ sucrose were determined as $25.96 \mathrm{mg} / \mathrm{g}, 24.76 \mathrm{mg} / \mathrm{g}$, $26.13 \mathrm{mg} / \mathrm{g}$, and $28.80 \mathrm{mg} / \mathrm{g}$ for $C$. membranaefaciens, $C$. utilis, C. tropicalis, C. lipolytica, respectively (Fig. 5). Although removal efficiency increased with increasing initial sucrose concentration for all yeasts, it decreased with increasing initial metal ion concentrations. Uptake efficiency significantly decreased from $88.80 \%$ to $56.44 \%$ with an increase in the initial $\mathrm{Cu}$ (II) concentration from 25 to $200 \mathrm{mg} / \mathrm{L}$ for $C$. lipolytica at $20 \mathrm{~g} / \mathrm{L}$ constant sucrose concentration (Table 4). This decrease may result from metal-binding sites on yeast surfaces. It was reported that binding sites were occupied first rapidly, then decreased with increasing metal concentrations (Honfi et al. 2016).

The bioaccumulated $\mathrm{Cu}(\mathrm{II})$ concentrations were higher than bioaccumulated $\mathrm{Ni}$ (II) concentrations in growth media containing $25 \mathrm{mg} / \mathrm{L}$ single $\mathrm{Cu}(\mathrm{II})$ and $\mathrm{Ni}$ (II) ions (Figs 2, 3).

The intolerance of living cells to high metal concentrations limits bioaccumulation process, but living cells have the potential genetic recombination to improve the metal-adapted strain (Malik 2004). Heavy metal bioaccumulation capacity of Candida species was strongly $\mathrm{pH}$-dependent due to changing solution chemistry and active functional groups on the biomass. Due to the $\mathrm{Ni}$ (II) inhibition effect, metal uptake performance decreased from $81.68 \%$ to $46.28 \%$ with increasing $\mathrm{Ni}(\mathrm{II})$ concentration from 25 to $250 \mathrm{mg} / \mathrm{L}$ for C. lipolytica. According to Gönen and Aksu (2008), C. utilis accumulated toxic heavy metals. The uptake efficiency of $\mathrm{Cu}$ (II) by $C$. utlis was observed as $27.0 \%$ in a growth medium containing $11.2 \mathrm{~g} / \mathrm{L}$ sucrose and 101.3 $\mathrm{mg} / \mathrm{L} \mathrm{Cu}$ (II) ions (Gönen \& Aksu 2008). Pawan and Devi (2018) investigated bioaccumulation of $\mathrm{Ni}(\mathrm{II}), \mathrm{Zn}$ (II), $\mathrm{Cr}(\mathrm{VI})$ by Aspergillus awamori, A. flavus and A. niger and found that $A$. niger was a highly tolerant strain. Maximum dry weight of A. flavus was found as $12.31 \mathrm{~g} / \mathrm{L}$ for $\mathrm{Ni}(\mathrm{II})$ in medium containing $100 \mathrm{mg} / \mathrm{L}$ initial broth concentration (Pawan \& Devi 2018). Rehman and Anjum (2010) reported that Candida tropicalis was a metalresistant yeast. They reported that $C$. tropicalis bioaccumulated $64 \%$ copper from industrial wastewater after 4 days (Rehman \& Anjum 2010).

Table 3. Comparison of decrease in maximum dried microorganism concentrations obtained in the metal-free fermentation media with $\mathrm{Cu}(\mathrm{II})$ and $\mathrm{Ni}(\mathrm{II})$ ions present as the single metal at 100 and $250 \mathrm{mg} / \mathrm{L}$ (So: $10 \mathrm{~g} / \mathrm{L} ; \mathrm{pH}: 4, \mathrm{~T}: 25^{\circ} \mathrm{C}$; SR: $150 \mathrm{rpm}$ ).

\begin{tabular}{|c|c|c|c|c|c|c|c|c|c|}
\hline \multicolumn{2}{|c|}{ Metal Ion } & \multicolumn{2}{|c|}{ C. membranefeciens } & \multicolumn{2}{|c|}{ C. utilis } & \multicolumn{2}{|c|}{ C.tropicalis } & \multicolumn{2}{|c|}{ C. lipolytica } \\
\hline $\begin{array}{c}\mathrm{C}_{\mathrm{iCu}} \\
(\mathrm{mg} / \mathrm{L})\end{array}$ & $\begin{array}{c}\mathrm{C}_{\mathrm{iNi}} \\
(\mathrm{mg} / \mathrm{L}) \\
\end{array}$ & $\begin{array}{l}\mathbf{X}_{\max } \\
(\mathbf{g} / \mathbf{L}) \\
\end{array}$ & $\begin{array}{c}\text { Decrease } \\
\% \\
\end{array}$ & $\begin{array}{l}\mathbf{X}_{\max } \\
(\mathrm{g} / \mathrm{L}) \\
\end{array}$ & $\begin{array}{c}\text { Decrease } \\
\% \\
\end{array}$ & $\begin{array}{l}\mathbf{X}_{\max } \\
(\mathrm{g} / \mathrm{L}) \\
\end{array}$ & $\begin{array}{c}\text { Decrease } \\
\% \\
\end{array}$ & $\begin{array}{l}\mathbf{X}_{\max } \\
(\mathrm{g} / \mathrm{L}) \\
\end{array}$ & $\begin{array}{c}\text { Decrease } \\
\% \\
\end{array}$ \\
\hline 100.0 & 0.0 & 2.666 & 2.4 & 2.456 & 7.6 & 2.831 & 5.6 & 2.968 & 4.6 \\
\hline 250.0 & 0.0 & 2.335 & 14.5 & 2.148 & 19.2 & 2.483 & 17.2 & 2.607 & 16.2 \\
\hline 0.0 & 100.0 & 2.574 & 5.8 & 2.371 & 10.8 & 2.735 & 8.8 & 2.868 & 7.8 \\
\hline 0.0 & 250.0 & 2.175 & 20.4 & 1.199 & 54.9 & 2.315 & 22.8 & 2.432 & 21.8 \\
\hline
\end{tabular}




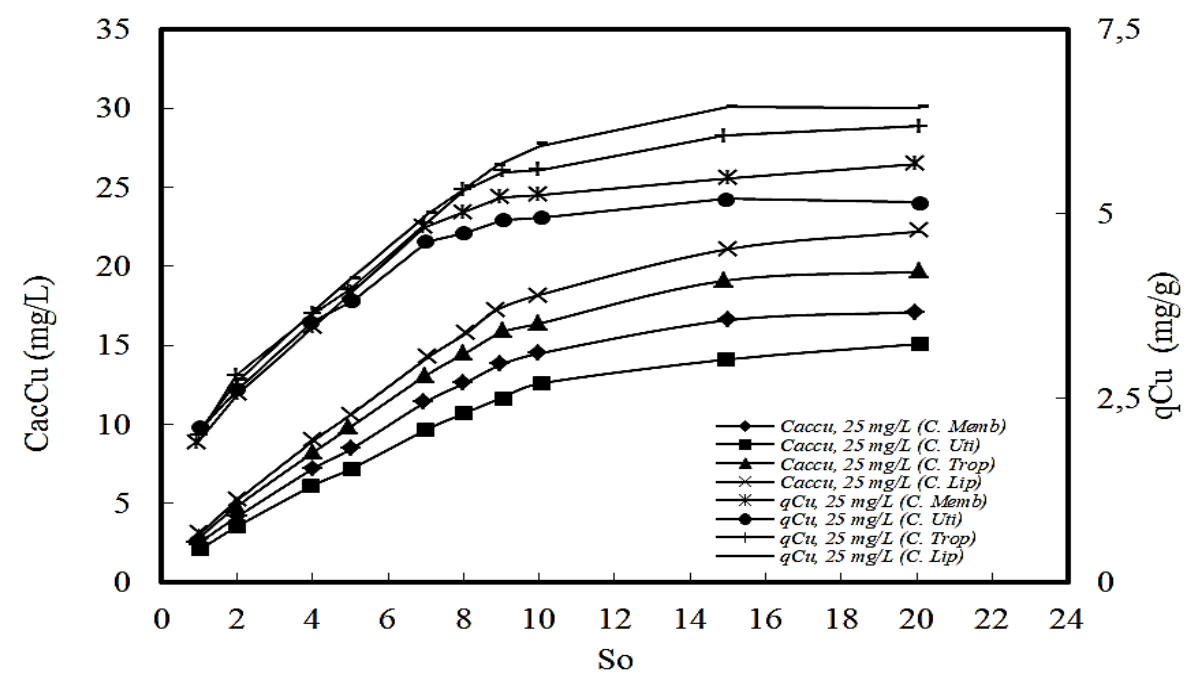

Fig. 2. Effect of initial sucrose concentration on the bioaccumulated $\mathrm{Cu}(\mathrm{II})$ ion quantity per unit weight of dried biomass and specific $\mathrm{Cu}(\mathrm{II})$ uptake in the presence of $25 \mathrm{mg} / \mathrm{L} \mathrm{Cu}(\mathrm{II})\left(\mathrm{pH}: 4.0\right.$; SR: $\left.150 \mathrm{rpm} ; \mathrm{T}: 25^{\circ} \mathrm{C}\right)$.

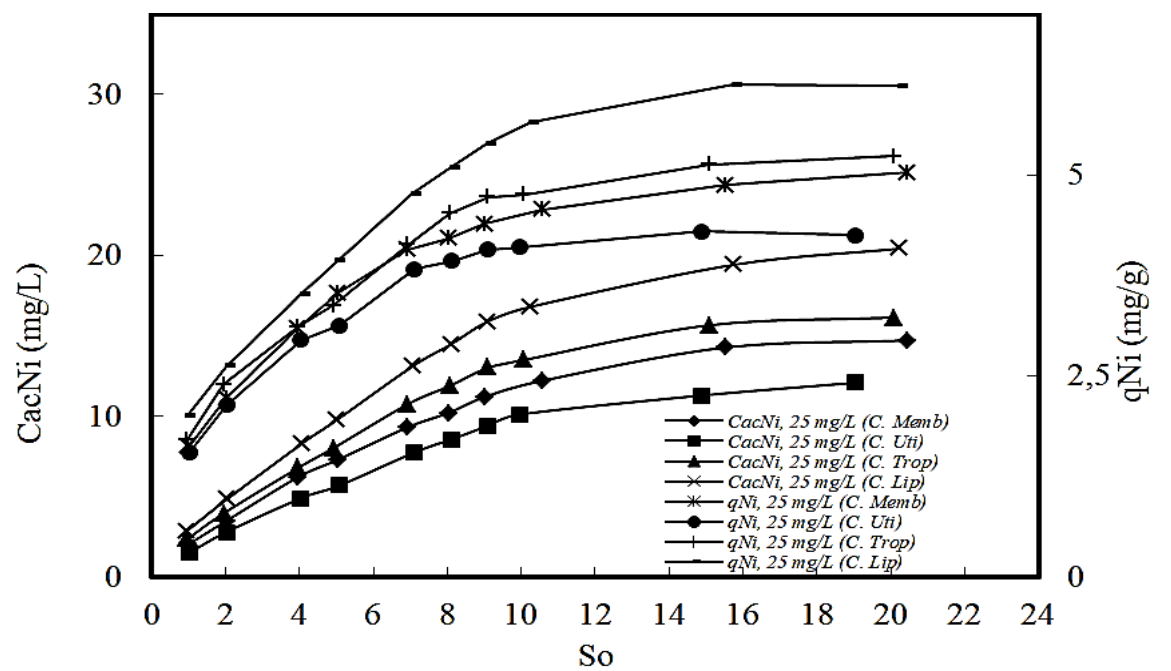

Fig. 3. Effect of initial sucrose concentration on the bioaccumulated $\mathrm{Ni}(\mathrm{II})$ ion quantity per unit weight of dried biomass and specific $\mathrm{Ni}$ (II) uptake in the presence of $25 \mathrm{mg} / \mathrm{L} \mathrm{Ni}(\mathrm{II})\left(\mathrm{pH}: 4.0\right.$; SR: $150 \mathrm{rpm}$; $\left.\mathrm{T}: 25^{\circ} \mathrm{C}\right)$.

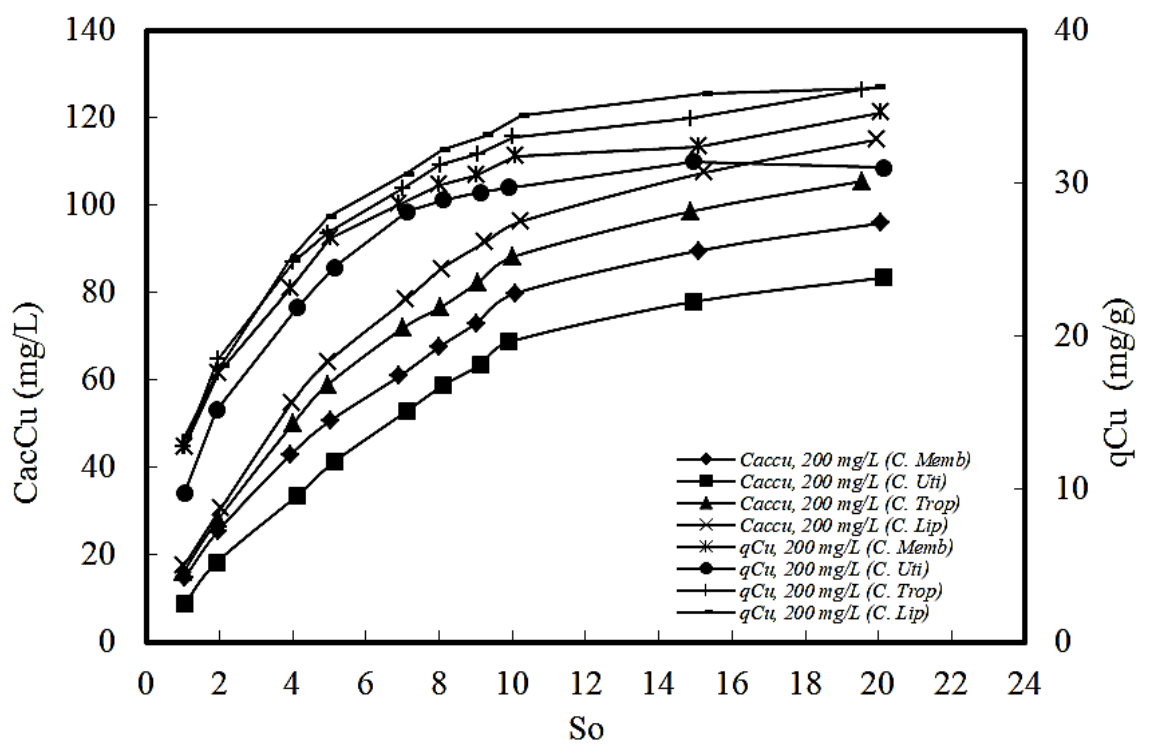

Fig. 4. Effect of initial sucrose concentration on the bioaccumulated $\mathrm{Cu}(\mathrm{II})$ ion quantity per unit weight of dried biomass and specific $\mathrm{Cu}$ (II) uptake in the presence of $200 \mathrm{mg} / \mathrm{L} \mathrm{Cu}$ (II) (pH: 4.0; SR: $150 \mathrm{rpm}$; T: $25^{\circ} \mathrm{C}$ ). 


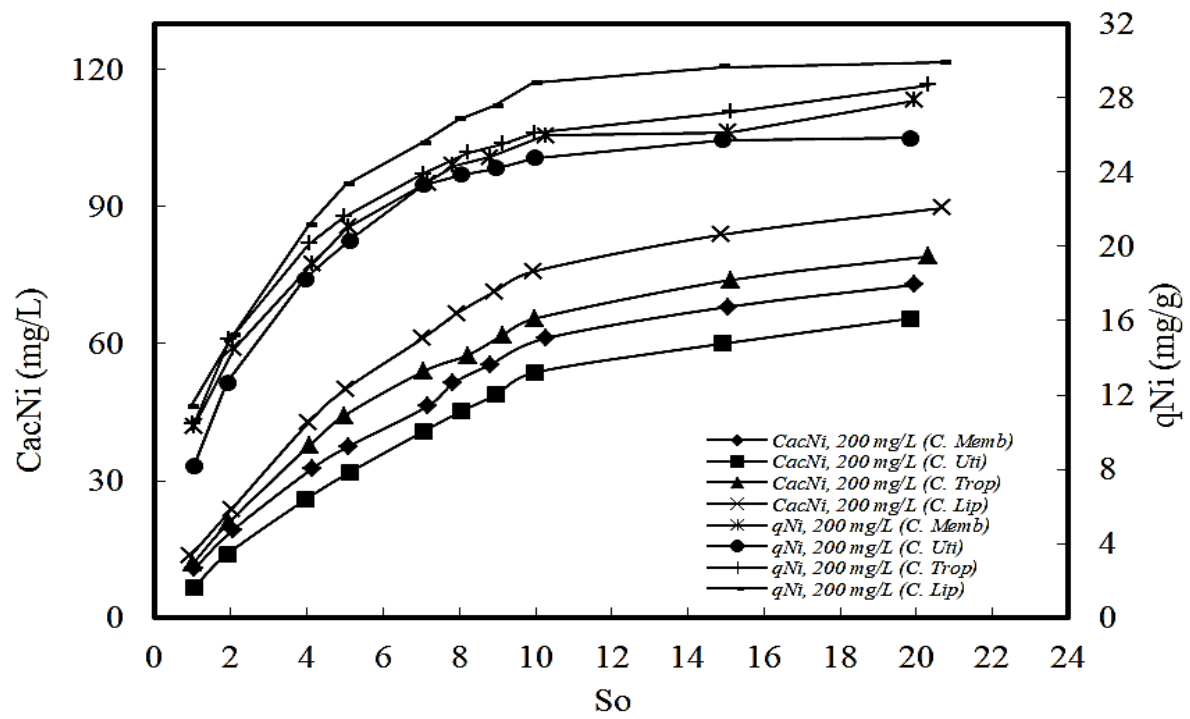

Fig. 5. Effect of initial sucrose concentration on the bioaccumulated $\mathrm{Ni}(\mathrm{II})$ ion quantity per unit weight of dried biomass and specific $\mathrm{Ni}(\mathrm{II})$ uptake in the presence of $200 \mathrm{mg} / \mathrm{L} \mathrm{Ni}(\mathrm{II})\left(\mathrm{pH}: 4.0\right.$; SR: $150 \mathrm{rpm}$; T: $25^{\circ} \mathrm{C}$ ).

Table 4. Comparison of the bioaccumulated $\mathrm{Cu}$ (II) and $\mathrm{Ni}(\mathrm{II})$, the $\mathrm{Cu}(\mathrm{II})$ and $\mathrm{Ni}$ (II) metal ion bioaccumulation efficiency in the fermentation media containing single $\mathrm{Cu}(\mathrm{II})$ and $\mathrm{Ni}(\mathrm{II})$ ions (pH: $4.0 ; \mathrm{T}: 25^{\circ} \mathrm{C} ; \mathrm{SR}: 150 \mathrm{rpm}$.

\begin{tabular}{|c|c|c|c|c|c|c|c|c|c|}
\hline \multicolumn{2}{|c|}{ Yeast } & \multicolumn{2}{|c|}{ C. membranaefaciens } & \multicolumn{2}{|c|}{ C. utilis } & \multicolumn{2}{|c|}{ C. tropicolis } & \multicolumn{2}{|c|}{ C.lipolytica } \\
\hline $\begin{array}{c}\begin{array}{c}S_{\mathbf{i}} \\
(\mathrm{g} / \mathrm{L})\end{array} \\
\end{array}$ & $\begin{array}{c}\begin{array}{c}\mathbf{C}_{\mathrm{i}, \mathrm{Cu}} \\
(\mathrm{mg} / \mathrm{L})\end{array} \\
\end{array}$ & $\begin{array}{c}\mathrm{C}_{\mathrm{ac}, \mathrm{Cu}} \\
(\mathrm{mg} / \mathrm{L}) \\
\end{array}$ & $\begin{array}{c}\text { Uptake } \\
(\%) \\
\end{array}$ & $\begin{array}{c}\mathrm{C}_{\mathrm{ac}, \mathrm{Cu}} \\
(\mathrm{mg} / \mathrm{L})\end{array}$ & $\begin{array}{c}\text { Uptake } \\
(\%)\end{array}$ & $\begin{array}{c}\mathbf{C}_{\mathbf{a c}, \mathrm{Cu}} \\
(\mathrm{mg} / \mathrm{L})\end{array}$ & $\begin{array}{c}\text { Uptake } \\
(\%)\end{array}$ & $\begin{array}{c}\mathrm{C}_{\mathrm{ac}, \mathrm{Cu}} \\
(\mathrm{mg} / \mathrm{L})\end{array}$ & $\begin{array}{c}\text { Uptake } \\
(\%)\end{array}$ \\
\hline 1 & & 2.50 & 10.00 & 2.13 & 8.52 & 2.88 & 11.52 & 3.13 & 12.52 \\
\hline 10 & 25 & 14.50 & 58.00 & 12.60 & 50.40 & 16.40 & 65.60 & 18.20 & 72.80 \\
\hline 20 & & 17.10 & 68.40 & 15.1 & 60.4 & 19.67 & 78.68 & 22.20 & 88.80 \\
\hline 1 & & 6.88 & 6.88 & 5.50 & 5.50 & 7.56 & 7.56 & 8.70 & 8.70 \\
\hline 10 & 100 & 46.80 & 46.80 & 38.40 & 38.40 & 51.48 & 51.48 & 59.20 & 59.20 \\
\hline 20 & & 58.47 & 58.47 & 46.77 & 46.77 & 64.31 & 64.31 & 73.96 & 73.96 \\
\hline 1 & & 14.60 & 7.30 & 8.65 & 23.38 & 16.06 & 8.03 & 17.51 & 8.75 \\
\hline 10 & 200 & 79.80 & 39.90 & 68.70 & 20.67 & 88.20 & 44.10 & 96.30 & 48.15 \\
\hline 20 & & 95.88 & 47.94 & 83.37 & 34.35 & 105.46 & 52.73 & 114.96 & 57.48 \\
\hline 1 & & 11.60 & 4.64 & 8.50 & 3.40 & 15.20 & 6.08 & 16.42 & 6.56 \\
\hline 10 & 250 & 94.81 & 37.92 & 79.01 & 31.60 & 104.29 & 41.71 & 112.60 & 45.04 \\
\hline 20 & & 115.05 & 46.02 & 95.88 & 38.35 & 126.56 & 50.62 & 141.10 & 56.44 \\
\hline $\begin{array}{c}S_{\mathbf{o}} \\
(\mathrm{g} / \mathrm{L})\end{array}$ & $\begin{array}{c}\mathrm{C}_{\mathrm{i}, \mathrm{Ni}} \\
(\mathrm{mg} / \mathrm{L})\end{array}$ & $\begin{array}{c}\mathrm{C}_{\mathrm{ac}, \mathrm{Ni}} \\
(\mathrm{mg} / \mathrm{L})\end{array}$ & $\begin{array}{c}\text { Uptake } \\
(\%)\end{array}$ & $\begin{array}{c}\mathrm{C}_{\mathrm{ac}, \mathrm{Ni}} \\
(\mathrm{mg} / \mathrm{L})\end{array}$ & $\begin{array}{c}\text { Uptake } \\
(\%)\end{array}$ & $\begin{array}{c}\mathrm{C}_{\mathrm{ac}, \mathrm{Ni}} \\
(\mathrm{mg} / \mathrm{L})\end{array}$ & $\begin{array}{c}\text { Uptake } \\
(\%)\end{array}$ & $\begin{array}{c}\mathrm{C}_{\mathrm{ac}, \mathrm{Ni}} \\
(\mathrm{mg} / \mathrm{L})\end{array}$ & $\begin{array}{c}\text { Uptake } \\
(\%)\end{array}$ \\
\hline 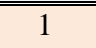 & & 2.04 & 8.16 & 1.51 & ב6.04 & 2.36 & 9.44 & 2.88 & 111.52 \\
\hline 10 & 25 & 12.20 & 48.80 & 10.10 & 40.40 & 13.50 & 54.00 & 16.8 & 67.20 \\
\hline 20 & & 14.71 & 58.84 & 12.08 & 48.32 & 16.13 & 64.52 & 20.42 & 81.68 \\
\hline 1 & & 5.84 & 5.84 & 4.47 & 4.47 & 6.50 & 6.50 & 7.39 & 7.39 \\
\hline 10 & 100 & 39.70 & 39.70 & 31.20 & 31.20 & 44.30 & 44.30 & 50.70 & 50.70 \\
\hline 20 & & 49.70 & 49.70 & 38.80 & 38.80 & 55.31 & 55.31 & 62.86 & 62.86 \\
\hline 1 & & 10.80 & 5.40 & 6.66 & 3.33 & 12.05 & 6.02 & 13.65 & 6.82 \\
\hline 10 & 200 & 61.20 & 30.60 & 53.70 & 26.85 & 65.50 & 32.75 & 75.80 & 37.90 \\
\hline 20 & & 72.87 & 36.43 & 65.50 & 32.75 & 79.10 & 39.55 & 89.67 & 44.83 \\
\hline 1 & 250 & 8.82 & 3.52 & 6.63 & 2.65 & 10.50 & 4.20 & 13.46 & 5.38 \\
\hline 10 & 250 & 72.20 & 28.88 & 62.10 & 24.84 & 79.26 & 31.70 & 92.33 & 36.93 \\
\hline 20 & & 87.44 & 34.97 & 78.70 & 31.48 & 96.18 & 38.47 & 115.70 & 46.28 \\
\hline
\end{tabular}

The physiological and biochemical properties of microorganisms can be changed by the presence of heavy metals. Heavy metals such as copper $(\mathrm{Cu}(\mathrm{I})$ and $\mathrm{Cu}(\mathrm{II})$ ) carry soluble electrons and can catalyze Fenton and Haber-Weiss reactions. Cytoplasmic molecules in microorganisms can cause serious damage to DNA, lipids and other proteins (Giner-Lamia et al. 2014). Heavy metal can cause ion imbalance by binding to the cell surface and entering through ion channels or transmembrane carriers (Chen et al. 2014). High vitamin and mineral contents of molasses sucrose stimulate microorganisms growth (Razack et al. 2013). The structure of metal-binding agents (homopolysaccharides, single saccharides, and acid components) in microorganisms and their distributions in the cell wall determine the metal accumulation capacity (Raspor \& Zupan 2006). Heavy 
metal cations can interact with some cations on the cell wall. The cell wall and heavy metal interactions may inhibit the function of physiological cations in the cell structure. As a result of this inhibition, oxidative stress occurs in the cell. For example, $\mathrm{Fe}, \mathrm{Zn}$, and $\mathrm{Ca}$ affect the uptake and toxicity of heavy metals in microorganisms. $\mathrm{Ca}$ and $\mathrm{Fe}$ ions reduce the uptake of $\mathrm{Cd}$ (Volland et al. 2014). Metal uptake is mainly related to the concentrations of metals in solution (Modak \& Natarajan 1995). Also, intercellular electrostatic interactions in cells play an important role in metal uptake capacity. At a certain equilibrium, biomass adsorbs more metal ions at lower cell concentrations (Gourdon et al. 1990). The inhibition effect of heavy metals on microorganism growth depends on the total metal ion concentration, the chemical structure of the metal, and redox potential of metal. Environmental factors such as temperature, $\mathrm{pH}$, organic acids, and humic acids can alter the conversion, transport, valence of heavy metals, and the resistance of microorganisms to heavy metals.

\section{Conclusion}

In the present study, microbial growth and bioaccumulation properties of Candida biomasses were investigated as a function of molasses sucrose and metal ion concentrations in a batch reactor. Optimum $\mathrm{pH}$ was found 4.0 for each yeast and all experiment conducted at this $\mathrm{pH}$ value. Biomass concentrations and specific growth rates increased with increasing initial sucrose concentration in metal and metal-free media. Both $\mathrm{Cu}$ (II) and $\mathrm{Ni}$ (II) inhibited specific growth rates and the contribution of $\mathrm{Cu}$ (II) inhibition was lower than $\mathrm{Ni}$ (II). Thus, the maximum specific growth rates of yeasts decreased with increasing initial metal ion concentrations. The saturation constants were determined in both metal and metal-free fermentation medium. Saturation constants

\section{References}

1. Açikel, U. \& Alp, T. 2009. A study on the inhibition kinetics of bioaccumulation of $\mathrm{Cu}$ (II) and $\mathrm{Ni}$ (II) ions using Rhizopus delemar. Journal of Hazardous Materials, 168(23): 1449-1458. https://doi.org/10.1016/j.jhazmat.2009.03.040

2. Aksu, Z. \& Dönmez, G. 2000. The use of molasses in copper (II) containing wastewaters: effects on growth and copper (II) bioaccumulation properties of Kluyveromyces marxianus. Process Biochemistry, 36(5): 451-458. https://doi.org/10.1016/S0032-9592(00)00234-X

3. Baysal, Z., Çinar, E., Bulut, Y., Alkan, H. \& Dogru, M. 2009. Equilibrium and thermodynamic studies on biosorption of $\mathrm{Pb}(\mathrm{II})$ onto Candida albicans biomass. Journal of Hazardous Materials, 161(1): 62-67. https://doi.org/10.1016/j.jhazmat.2008.02.122

4. Brady, D. \& Duncan, J.R. 1994. Bioaccumulation of metal cations by Saccharomyces cerevisiae. Applied Microbiology and Biotechnology, 41: 149-154. https://doi.org/10.1007/BF00166098

5. Chen, S., Yin, H., Ye, J., Peng, H., Liu, Z., Dand, Z. \& Chang, J. 2014. Influence of co-existed benzo[a]pyrene and and the amounts of $\mathrm{Cu}(\mathrm{II})$ and $\mathrm{Ni}(\mathrm{II})$ ions uptake per gram dry biomass increased with the increase of the initial concentration of heavy metals ions. The removal efficiency of $\mathrm{Cu}(\mathrm{II})$ ions was higher than $\mathrm{Ni}(\mathrm{II})$, and Candida lipolytica showed maximum uptake efficiency in fermentation medium containing $\mathrm{Cu}$ (II) and $\mathrm{Ni}$ (II) ions. Results showed that bioaccumulation of $\mathrm{Cu}$ (II) and $\mathrm{Ni}$ (II) ions by Candida biomass was metabolism dependent. Candida biomasses showed different bioaccumulative capacities for the same metal ions. The yeast surface properties and cell wall components may change affinity and cell-metal interaction. In addition, environmental conditions can affect the accumulation capacity of yeasts. Although $\mathrm{Cu}$ (II) and $\mathrm{Ni}$ (II) have similar chemical properties, genetic differences of yeasts and the chemical nature of metals caused differences in bioaccumulation performances. This study showed that Candida biomasses are useful for removal $\mathrm{Cu}$ (II) and $\mathrm{Ni}$ (II) ions from aqueous solutions. The comparison of bioaccumulation properties of Candida yeasts may help to an effective selection of Candida strains for water treatments.

Ethics Committee Approval: Since the article does not contain any studies with human or animal subject, its approval to the ethics committee was not required.

Author Contributions: Execution: G.M., Data analysis/interpretation: Ü.A., Writing: G.M., Critical Review: Ü.A.

Conflict of Interest: The authors have no conflicts of interest to declare.

Funding: This research was supported by Cumhuriyet University Scientific Research Projects Unit (Project Number: BAP- M-354).

copper on the cellular characteristics of Stenotrophomonas maltophilia during biodegradation and transformation. Bioresource Technology, 158: 181-187. https://doi.org/10.1016/j.biortech.2014.02.020

6. Cottet, C., Ramirez-Tapias, Y.A., Delgado, J.F., de la Osa, O., Salvay, A.G. \& Peltzer, M.A. 2020. Biobased Materials from Microbial Biomass and Its Derivatives. Materials, 13(6): 1263. https://doi.org/10.3390/ma13061263

7. Dupont, C.L., Grass, G. \& Rensing, C. 2011. Copper toxicity and the origin of bacterial resistance-New insights and applications. Metallomics, (3): 1109-1118. https://doi.org/10.1039/c1mt00107h

8. Evirgen, O.A. \& Sag Acikel, Y. 2014. Simultaneous copper bioaccumulation, growth and lipase production of Rhizopus delemar in molasses medium: optimisation of environmental conditions using RSM. Chemistry and Ecology, 30(1): 39-51. https://doi.org/10.1080/02757540.2013.827670

9. Fadel M., Hassanein, N.M., Elshafei, M.M., Mostafa, A.H., Ahmed, M.A. \& Khater, H.M. 2017. Biosorption of manganese from groundwater by biomass of 
Saccharomyces cerevisiae. HBRC Journal. 13(1): 106-113. https://doi.org/10.1016/j.hbrcj.2014.12.006

10. Fashola, M.O., Ngole-Jeme, V.M. \& Babalola, O.O. 2016. Heavy metal pollution from gold mines: Environmental effects and bacterial strategies for resistance. International Journal of Environmental Research and Public Health, (13): 1047. https://doi.org/10.3390/ijerph13111047

11. Giner-Lamia, J., L'opez-Maury, L., Florencio, F.J. \& Janssen, P.J. 2014. Global transcriptional profiles of the copper responses in the cyanobacterium synechocystis sp. PCC 6803. PLOS ONE, 9 (9): e108912. https://doi.org/10.1371/journal.pone.0108912

12. Gönen, F. \& Aksu, Z. 2008. Use of response surface methodology (RSM) in the evaluation of growth and copper(II) bioaccumulation properties of Candida utilis in molasses medium. Journal of Hazardous Materials, 154(13): 731-738. https://doi.org/10.1016/j.jhazmat.2007.10.086

13. Gourdon, R., Bhende, S., Rus, E. \& Sofer, S.S. 1990. Comparison of cadmium biosorption by Gram-positive and Gram-negative bacteria from activated sludge. Biotechnology Letters, 12: 839-842. https://doi.org/10.1007/BF01022606

14. Honfi, K., Tálos, K., Kőnig-Péter, A., Kilár, F. \& Pernyeszi, T. 2016. Copper(II) and Phenol Adsorption by Cell Surface Treated Candida tropicalis Cells in Aqueous Suspension. Water, Air \& Soil Pollution, 227: 1-14. https://doi.org/10.1007/s11270-016-2751-0

15. Javanbakht, V., Alavi, S.A. \& Zilouei, H. 2013. Mechanisms of heavy metal removal using microorganisms as biosorbent. Water Science and Technology, 69(9): 17751787. https://doi.org/10.2166/wst.2013.718

16. Legorreta-Castañeda, A.J., Lucho-Constantino, C.A., Beltrán-Hernández, R.I., Coronel-Olivares, C. \& VázquezRodríguez, G.A. 2020. Biosorption of Water Pollutants by Fungal Pellets. Water, 12(4): 11551193. https://doi.org/10.3390/w12041155

17. Liu, Y. 2007. Overview of some theoretical approaches for derivation of the Monod equation. Applied Microbiology and Biotechnology, 73: 1241-1250 https://doi.org/10.1007/s00253-006-0717-7

18. Luk, C.H.J., Yip, J., Yuen, C.W.M., Pang, S.W., Lam, K.H. \& Kan, C.W. 2017. Biosorption Performance of Encapsulated Candida krusei for the removal of Copper(II). Scientific Reports, 7: 1-9. https://doi.org/10.1038/s41598-017-02350-7

19. Luna, J.M., Rufino, R.D. \& Sarubbo, L.A. 2016. Biosurfactant from Candida sphaerica UCP0995 exhibiting heavy metal remediation properties. Process Safety and Environmental Protection, 102: 558-566. https://doi.org/10.1016/j.psep.2016.05.010

20. Malik, A. 2004. Metal bioremediation through growing cells. Environment International, 30(2): 261-78. https://doi.org/10.1016/j.envint.2003.08.001

21. Modak, J.M. \& Natarajan, K.A. 1995. Biosorption of metals using nonliving biomass-A review. Mining, Metallurgy \& Exploration, 12: 189-196. https://doi.org/10.1007/BF03403102

22. Monod, J. 1949. The growth of bacterial cultures. Annual Reviews in Microbiology, 3(1): 371-394. https://mcb.berkeley.edu/labs/garcia/sites/mcb.berkeley.edu. labs.garcia/files/Teaching/2017-MCB137/Monod1949.pdf (Date accessed: 22.11.2020)

23. Pawan, K.R. \& Devi, R. 2018. Heavy metal tolerance and adaptability assessment of indigenous filamentous fungi isolated from industrial wastewater and sludge samples. Beni-Suef University Journal of Basic and Applied Sciences, 7(4): 688-694. https://doi.org/10.1016/j.bjbas.2018.08.001

24. Podder, M.S. \& Majumder, C.B. 2019. Bacteria immobilization on neem leaves/MnFe2O4 composite surface for removal of As(III) and As(V) from wastewater. Arabian Journal of Chemistry, 12: 3263-3288. https://doi.org/10.1016/j.arabjc.2015.08.025

25. Raspor P. \& Zupan J. 2006. Yeasts in Extreme Environments. pp. 371-372. In: Péter G.\& Rosa C.A. (eds). Biodiversity and Ecophysiology of Yeasts. SpringerVerlang, Berlin, 580 pp. https://doi.org/10.1007/3-540$\underline{\text { 30985-3_15 }}$

26. Razack, S.A., Velayutham, V. \& Thangavelu, V. 2013. Medium optimization for the production of exopolysaccharide by Bacillus subtilis using synthetic sources and agro wastes. Turkish Journal of Biology, 37: 280-288. https://doi.org/10.3906/biy-1206-50

27. Redha, A.A. 2020. Removal of heavy metals from aqueous media by biosorption. Arab Journal of Basic and Applied Sciences, $27(1)$ : https://doi.org/10.1080/25765299.2020.1756177

28. Rehman, A. \& Anjum, M.S. 2011. Multiple metal tolerance and biosorption of cadmium by Candida tropicalis isolated from industrial effluents: glutathione as detoxifying agent. Environmental Monitoring and Assessment, 174: 585-595. https://doi.org/10.1007/s10661-010-1480-x

29. Rehman, A. \& Anjum, M.S. 2010. Cadmium Uptake by Yeast, Candida tropicalis, Isolated from Industrial Effluents and Its Potential Use in Wastewater Clean-Up Operations. Water, Air and Soil Pollution, 205: 149-159. https://doi.org/10.1007/s11270-009-0062-4

30. Şengör, S.S., Barua, S., Gikas, P., Ginn, T.R., Peyton, B., Sani, R.K., \& Spycher, N.F. 2009. Influence Of Heavy Metals On Microbial Growth Kinetics Including Lag Time: Mathematical Modeling And Experimental Verification. Environmental Toxicology and Chemistry, 28: 2020-2029. https://doi.org/10.1897/08-273.1

31. Sandell, E.B. 1950. Colorimetric Determination of Traces of Metals Volume III. pp. 304-475. In: Clarke, B.L. \& Kolthoff, I.M. (eds). Chemical Analysis A Series of Monographs on Analytical Chemistry And Its Applications. Interscience Publishers INC, London, 688 pp.

32. Tchounwou, P.B., Yedjou, C.G., Patlolla, A.K. \& Sutton, D. J. 2012. Heavy metal toxicity and the environment. Experientia Supplementum, 101: 133-164. https://doi.org/10.1007/978-3-7643-8340-4_6

33. Tripathi, A, \& Ranjan, M.R. 2015. Heavy Metal Removal from Wastewater Using Low Cost Adsorbents. Journal of Bioremediation \& Biodegration, 6: 315-320. http://dx.doi.org/10.4172/2155-6199.1000315

34. Volland, S., Bayer, E., Baumgartner, V., Andosch, A., Lütz, C., Sima, E. \& Lütz-Meindl, U. 2014. Rescue of 
heavy metal effects on cell physiology of the algal model system Micrasterias by divalent ions. Journal of Plant Physiology, 171(2): 154-163. https://doi.org/10.1016/j.jplph.2013.10.002

35. Waldron, K.J. \& Robinson, N.J. 2009. How do bacterial cells ensure that metalloproteins get the correct metal? Nature Reviews Microbiology, 7: 25-35. https://doi.org/10.1038/nrmicro2057

36. Wołowiec, M., Komorowska-Kaufman, M., Pruss, A., Rzepa, G. \& Bajda, T. 2019. Removal of Heavy Metals and
Metalloids from Water Using Drinking Water Treatment Residuals as Adsorbents: A Review. Minerals, 9(8): 487504. https://doi.org/10.3390/min9080487

37. Zha, F., Wang, H., Xu, L., Yang, C., Kang, B., Chu, C., Deng, Y. \& Tan, X. 2020. Initial feasibility study in adsorption capacity and mechanism of soda residue on lead (II)-contaminated soil in solidification/stabilization technology. Environmental Earth Sciences, 79: 1-12. https://doi.org/10.1007/s12665-020-08990-9 